\title{
Pengaruh Penambahan Lumpur Geothermal dan Serat Baja Ban Bekas Terhadap Beton
}

\author{
Tri Yuhanah ${ }^{1}$, Devita Mayasari ${ }^{2}$, dan Budi Wicaksono ${ }^{3}$ \\ ${ }^{1,2,3}$ Sekolah Tinggi Teknik PLN \\ 1triyuhanah@gmail.com
}

\begin{abstract}
Concrete is a very popular construction material, widely used in construction. The waste that is in the surrounding environment begins to be used for mixed materials in the manufacture of concrete, one of which is geothermal mud (geothermal sludge) which has pozzolanic properties because it contains alumina silica minerals so that it can be used instead of cement. Waste steel fiber tires used residue from vehicles is an added material that can be used to improve the mechanical properties of concrete. This research aims to measure effects of adding geothermal mud and used steel fiber to concrete. Planned concrete fc '30 MPa with used tire steel fibers with variations of 0\%, 0,5\%, $1 \%$ and 1,5\% of the weight of concrete and geothermal mud as partial substitution of $20 \%$ cement. Concrete Variation 4 (1.5\% used tire steel fiber $+20 \%$ geothermal mud) has the highest compressive strength of $32.13 \mathrm{MPa}$ compared to normal concrete of $30.006 \mathrm{MPa}$. For the splitting tensile strength variation 4 is $1.8 \mathrm{MPa}$ and its flexural strength is $2.457 \mathrm{MPa}$ while the normal concrete is splitting tensile strength of $1.6 \mathrm{MPa}$ and its bending strength is $2.210 \mathrm{MPa}$.
\end{abstract}

Keywords: flexural strength, compressive strength, tensile strength, absorption, geothermal mud

\begin{abstract}
ABSTRAK
Beton merupakan material konstruksi yang sangat populer, banyak digunakan dalam bidang konstruksi. Limbah yang ada lingkungan sekitar mulai dimanfaatkan untuk bahan campuran dalam pembuatan beton, salah satunya lumpur geothermal (sludge geothermal) yang mempunyai sifat pozzolan karena mengandung mineral silika alumina sehingga dapat digunakan sebagai pengganti semen. Limbah serat baja ban bekas sisa pemakaian dari kendaraan merupakan bahan tambah yang dapat digunakan untuk memperbaiki sifat sifat mekanik beton. Tujuan dari penelitian ini, yaitu untuk mengukur pengaruh dari penambahan lumpur geothermal dan serat baja ban bekas terhadap beton. Beton direncanakan $f_{c}^{\prime} 30 \mathrm{MPa}$ dengan lumpur geothermal sebagai subtitusi sebagian semen $20 \%$ dan serat baja ban bekas dengan variasi 0\%, 0,5\%, 1\% dan 1,5\% berat beton. Beton Variasi 4 (1,5\% serat baja ban bekas $+20 \%$ lumpur geothermal) memiliki kuat tekan paling tinggi sebesar 32,13 MPa dengan perbandingan kuat tekan beton normal sebesar 30,006 MPa. Untuk kuat tarik belah variasi 4 sebesar 1,8 MPa dan kuat lenturnya 2,457 MPa sedangkan beton normal kuat tarik belah sebesar 1,6 MPa dan kuat lenturnya 2,210 MPa.
\end{abstract}

Kata kunci: kuat tarik, kuat lentur, kuat tekan, absorpsi, lumpur geothermal 


\section{PENDAHULUAN}

Beton merupakan material konstruksi yang banyak digunakan dalam bidang konstruksi. Semakin terbatasnya bahan material pembentuk beton tidak sebanding dengan banyaknya pengguna konstruksi beton sehingga diupayakan beton yang ramah lingkungan. Limbah yang ada lingkungan sekitar dimanfaatkan sebagai bahan campuran beton, salah satunya lumpur geothermal (sludge geothermal). Limbah padat geothermal mengandung unsur logam yang beberapa diantaranya logam berat, antara lain $\mathrm{Si}, \mathrm{Cu}, \mathrm{Pb}, \mathrm{Zn}, \mathrm{Mn}, \mathrm{Fe}, \mathrm{Cd}, \mathrm{As}, \mathrm{Sb}, \mathrm{Au}, \mathrm{Ag}, \mathrm{Hg}$, dan $\mathrm{Se}$. Lumpur limbah panas bumi atau lumpur geothermal (sludge geothermal) mempunyai sifat pozzolan karena mengandung mineral silika alumina sehingga dapat digunakan sebagai pengganti semen. Serbuk geothermal yang telah mengalami proses pembakaran berwarna putih sebanyak 15 - $30 \%$ dari berat lumpur yang dibakar dan mengandung silika sebagai komponen utama. Pada umumnya kadar silika dalam serbuk geothermal berkisar antara $75-85 \%$.

Penambahan serat pada beton dapat memperbaiki sifat-sifat antara lain meningkatkan kuat tarik, kuat lentur, ketahanan benturan, ketahanan keausan, fatigue, ketahanan susutan, ketahanan abrasi, ketahanan pecahan atau fragmentasi, ketahanan pengelupasan, serta modulus elastisitas. Serat dapat berupa limbah serat baja ban bekas sisa pemakaian dari kendaraan.

Penelitian ini perlu dilakukan untuk mengetahui pengaruh penambahan limbah lumpur Geothermal yang mengandung silica amorf $\left(\mathrm{SiO}_{2}\right)$ sebagai pengganti sebagian semen dan limbah serat baja ban bekas yang dapat memperbaiki sifat mekanik beton.

\section{METODE PENELITIAN}

Penelitian laboratorium terdiri atas pengujian fisis untuk persyaratan material bahan beton, kuat tekan, kuat tarik belah, nilai slump test (workability) dan absorpsi sesuai SNI. Prosedur penelitian adalah sebagai berikut:

A. Tahap Persiapan

Persiapan pengujian material utama, alat yang akan digunakan. Pembuatan benda uji akan dilaksanakan di Laboratorium Beton STT PLN.

B. Tahap Pelaksanaan

1. Pembuatan Benda Uji Penelitian

Pembuatan benda uji untuk penelitian sejumlah 65 benda uji dengan variasi lumpur geothermal sebagai subtitusi semen $20 \%$ dan serat baja ban bekas dengan variasi $0 \%$, 0,5\%, 1\%, 1,5\% dari berat beton. Pengujian benda uji pada umur 7, 14, dan 28 hari, bertujuan untuk mengukur kuat tekan dan kuat tarik belah beton yang diubah menjadi kuat lentur, absorpsi dan tes slump.

Besarnya tegangan tarik tidak langsung yang dialihkan saat beton itu mengalami belah, dapat dihitung menggunakan rumus ${ }^{[1]}$ :

$\mathrm{f}_{\mathrm{ct}}=\frac{2 \cdot P}{\pi \cdot L \cdot D}$

dimana:

$\mathrm{P}=$ Beban $(\mathrm{kg})$

$\mathrm{D}=$ Diameter silinder $(\mathrm{mm})$

$\mathrm{L}=$ Panjang silinder $(\mathrm{mm})$

Kuat tarik lentur ditentukan dari hasil uji kuat tarik belah beton sebagai berikut ${ }^{[3]}$ :

$\mathrm{f}_{\mathrm{cf}}=1,37 . \mathrm{f}_{\mathrm{ct}} \quad$ dalam MPa

dimana: 
$\mathrm{f}_{\mathrm{ct}}=$ kuat tarik belah beton

Nilai kuat tekan beton ditentukan dengan persamaan berikut ${ }^{[3]}$ :

$\mathrm{K}=\frac{P}{A}$

dimana:

$\mathrm{K}=$ kuat tekan $(\mathrm{MPa})$

$\mathrm{A}=$ Luas alas $\left(\mathrm{mm}^{2}\right)$

$\mathrm{P}=$ Beban $(\mathrm{N})$

Persamaan yang digunakan pada pengujian serapan air (absorpsi) adalah sebagai berikut ${ }^{[5]}$ :

$$
\text { Absorbsi }=\frac{B-A}{A} \times 100 \%
$$

dimana:

$\mathrm{A}=$ Berat Benda Uji Kering $(\mathrm{kg})$

$\mathrm{B}=$ Berat Benda Uji Setelah Direndam $(\mathrm{kg})$

2. Pengujian dan Pengumpulan Data

Tahap pelaksanaan yaitu melakukan pengujian terhadap benda uji yang telah dibuat dan kemudian melakukan pencatatan kuat tarik belah pada umur beton 7 hari, 14 hari dan 28 hari, dan pencatatan absorpsi pada umur 28 hari.

C. Tahap Analisa Data

Setelah data hasil pengujian diperoleh selanjutnya dilakukan analisa dan pembahasan perbandingan dengan beton normal yang bertujuan mengetahui nilai slump, kuat tekan, kuat tarik belah, kuat lentur beton, dan absorpsi.

D. Perumusan kesimpulan dan saran

Berdasarkan hasil analisis data dan pembahasan akan ditarik beberapa kesimpulan antara lain kuat tekan beton, kuat tarik belah beton dan kuat lentur beton serta absorpsi dan nilai tertinggi dan terendah slump dari variasi campuran.

\section{HASIL DAN PEMBAHASAN}

\section{A. Hasil Pengujian Geothermal}

Pengujian yang dilakukan adalah pemeriksaan berat satuan serbuk geothermal dengan berat awal $65 \mathrm{gr}$, volume minyak tanah $0,7 \mathrm{~cm}^{3}$, volume minyak tanah dan geothermal $22,5 \mathrm{~cm}^{3}$. Berdasarkan hasil dari pengujian berat satuan lumpur geothermal didapat hasil sebesar 2,98 $\mathrm{gr} / \mathrm{cm}^{3}$ yang memiliki nilai lebih kecil dibandingkan dengan berat satuan semen.

\section{B. Pengujian Agregat Halus}

1. Analisa Gradasi Pasir

Pengujian analisis gradasi pasir memperoleh hasil MHB 1,95\% memenuhi syarat ketetapan MHB pada rentang 1,50\% - 3,80\% ${ }^{[6]}$. Hasil analisa gradasi pasir termasuk zona IV termasuk kategori pasir halus.

Tabel 1. Batas dan Hasil Pengujian Gradasi Pasir ${ }^{[8]}$

\begin{tabular}{|c|c|c|c|c|c|}
\hline \multirow{2}{*}{$\begin{array}{c}\text { Lubang } \\
\begin{array}{c}\text { Ayakan } \\
(\mathrm{mm})\end{array}\end{array}$} & $\begin{array}{c}\text { Kasar } \\
(\text { Zona I) }\end{array}$ & $\begin{array}{c}\text { Agak Kasar } \\
(\text { Zona II) }\end{array}$ & $\begin{array}{c}\text { Agak Halus } \\
(\text { Zona III) }\end{array}$ & $\begin{array}{c}\text { Halus } \\
(\text { Zona IV) }\end{array}$ & $\begin{array}{c}\text { Pasir } \\
\text { Bangka }\end{array}$ \\
\cline { 2 - 6 } & 100 & 100 & 100 & 100 & 100 \\
\hline 4,50 & $90-100$ & $90-100$ & $90-100$ & $95-100$ & 99,940 \\
\hline
\end{tabular}




\begin{tabular}{|c|c|c|c|c|c|}
\hline 2,36 & $60-95$ & $75-100$ & $85-100$ & $95-100$ & 98,936 \\
\hline 1,18 & $30-75$ & $55-90$ & $75-100$ & $90-100$ & 93,115 \\
\hline 0,60 & $15-34$ & $33-59$ & $60-79$ & $80-100$ & 81,292 \\
\hline 0,30 & $5-20$ & $8-30$ & $12-40$ & $15-50$ & 29,706 \\
\hline 0,15 & $0-10$ & $0-10$ & $0-10$ & $0-15$ & 1,304 \\
\hline
\end{tabular}

2. Kandungan Lumpur Dalam Pasir

Rata-rata kandungan lumpur dalam pasir sebesar $1,378 \%$, yaitu memenuhi syarat yang ditetapkan $5 \%{ }^{[7]}$.

Tabel 2. Hasil Uji Kandungan Lumpur Dalam Pasir ${ }^{[8]}$

\begin{tabular}{|c|l|rc|}
\hline No & \multicolumn{1}{|c|}{ Keterangan } & Hasil \\
\hline 1 & Berat wadah $\left(\mathrm{W}_{1}\right)$ & $640 \quad \mathrm{gr}$ \\
\hline 2 & Berat benda uji + wadah $\left(\mathrm{W}_{2}\right)$ & $1.140 \quad \mathrm{gr}$ \\
\hline 3 & Berat benda uji $\left(\mathrm{W}_{3}\right)$ & $500 \quad \mathrm{gr}$ \\
\hline 4 & Berat kering benda uji di oven + wadah $\left(\mathrm{W}_{4}\right)$ & $1.133,2 \quad \mathrm{gr}$ \\
\hline 5 & Berat kering benda uji setelah di oven $\left(\mathrm{W}_{5}\right)$ & $493,2 \quad \mathrm{gr}$ \\
\hline 6 & $\%$ Kadar lumpur pasir $=\left(\frac{w 3-w 5}{w 5} \times 100 \%\right)$ & $1,378 \quad \%$ \\
\hline
\end{tabular}

(Sumber: Hasil analisis, 2018)

3. Kadar Air Pasir

Berdasarkan hasil pemeriksaan kadar air pasir diperoleh sebesar 5,507 \%. Berikut ini hasil dari pengujian kadar air pasir:

Tabel 3. Hasil Uji Kadar Air Pasir ${ }^{[8]}$

\begin{tabular}{|c|l|rl|}
\hline No & \multicolumn{1}{|c|}{ Keterangan } & \multicolumn{2}{c|}{ Hasil } \\
\hline 1 & Berat wadah $\left(\mathrm{W}_{1}\right)$ & $340 \quad \mathrm{gr}$ \\
\hline 2 & Berat benda uji + wadah $\left(\mathrm{W}_{2}\right)$ & $1.340 \quad \mathrm{gr}$ \\
\hline 3 & Berat benda uji $\left(\mathrm{W}_{3}\right)$ & $1.000 \quad \mathrm{gr}$ \\
\hline 4 & Berat benda uji setelah di oven + wadah $\left(\mathrm{W}_{4}\right)$ & $1.287,8 \mathrm{gr}$ \\
\hline 5 & Berat benda uji setelah di oven $\left(\mathrm{W}_{5}\right)$ & $947,8 \mathrm{gr}$ \\
\hline 6 & \% Kadar air pasir $=\left(\frac{w 3-w 5}{w 5} \times 100 \%\right)$ & $5,507 \%$ \\
\hline
\end{tabular}

(Sumber: Hasil analisis, 2018)

4. Berat Jenis Agregat Halus dan Absorpsi

Dari hasil uji berat jenis kering Pasir Bangka sebesar 2,98 dan untuk berat jenis dalam kondisi Saturated Surface Dry sebesar 3,03. Uji penyerapan air memberikan hasil sebesar $1,63 \%$. Berikut merupakan hasil uji berat jenis dan absorpsi agregat halus:

Tabel 4. Hasil Uji Berat Jenis Pasir dan Penyerapan Air ${ }^{[8]}$

\begin{tabular}{|c|l|c|}
\hline No. & \multicolumn{1}{|c|}{ Keterangan } & $\begin{array}{c}\text { Sample } \\
(\mathrm{gr})\end{array}$ \\
\hline $\mathrm{A}$ & Berat pasir (S) & 500 \\
\hline B & Berat pasir setelah dikeringkan (A) & 492 \\
\hline C & Berat air + piknometer (B) & 680 \\
\hline
\end{tabular}




\begin{tabular}{|c|l|c|}
\hline D & Berat piknometer+ 500 grpasir + air $(\mathrm{C})$ & 1.015 \\
\hline E & Berat jenis kering $\left(\frac{A}{(B+S)-c}\right)$ & 2,98 \\
\hline F & Saturated Surface Dry $\left(\frac{S}{(B+S)-C}\right)$ & 3,03 \\
\hline G & $\%$ Penyerapan $\left(\frac{S-A}{A} \times 100 \%\right)$ & $1,63 \%$ \\
\hline
\end{tabular}

(Sumber: Hasil analisis, 2018)

5. Kandungan Organis Dalam Pasir

Berdasarkan hasil pengujian kandungan organis dalam pasir dengan penambahan larutan $\mathrm{NaOh}$ didapatkan picmen colour adalah warna kuning (standar). Warna ini mengindikasikan kandungan organik dalam pasir tersebut normal.

\section{Pengujian Agregat Kasar}

1. Analisa Agregat Kasar (Kerikil)

Pengujian analisis gradasi agregat kasar menunjukkan hasil bahwa nilai MHB sebesar 6,325\%. Nilai MHB ini, memenuhi syarat yaitu MHB $6 \%-7,1 \%$. Hasil gradasi agregat kasar (kerikil) dapat dilihat pada tabel berikut:

Tabel 5. Hasil Uji Gradasi Kerikil dan Syarat Batas ${ }^{[8]}$

\begin{tabular}{|c|c|c|c|c|}
\hline \multirow{2}{*}{$\begin{array}{c}\text { Ukuran } \\
\text { Lubang }\end{array}$} & \multicolumn{4}{|c|}{ Persentase Berat Yang Lewat Ayakan } \\
\cline { 2 - 5 } & \multicolumn{3}{|c|}{ Ukuran Nominal Agregat } & Gradasi Kerikil \\
\cline { 2 - 5 } & $40 \mathrm{~mm}$ & $20 \mathrm{~mm}$ & $10 \mathrm{~mm}$ & $40 \mathrm{~mm}$ \\
\hline $38,10 \mathrm{~mm}$ & $95-100 \%$ & $100 \%$ & - & $95,90 \%$ \\
\hline $19,00 \mathrm{~mm}$ & $37-70 \%$ & $95-100 \%$ & $100 \%$ & $53,70 \%$ \\
\hline $9,52 \mathrm{~mm}$ & $10-40 \%$ & $30-60 \%$ & $50-85 \%$ & $10,98 \%$ \\
\hline $4,76 \mathrm{~mm}$ & $0-5 \%$ & $0-10 \%$ & $0-10 \%$ & $0 \%$ \\
\hline
\end{tabular}

(Sumber: Hasil analisis, 2018)

2. Kandungan Lumpur Dalam Kerikil

Hasil pengujian berupa kandungan lumpur dalam kerikil sebesar 0,402 \%, yaitu $<1 \%$ maka cukup baik digunakan.

Tabel 6. Hasil Uji Kandungan Lumpur Dalam Kerikil ${ }^{[8]}$

\begin{tabular}{|c|l|c|}
\hline No & \multicolumn{1}{|c|}{ Keterangan } & \multicolumn{1}{|c|}{ Hasil } \\
\hline 1 & Berat wadah $\left(\mathrm{W}_{1}\right)$ & $344 \mathrm{gr}$ \\
\hline 2 & Berat benda uji + wadah $\left(\mathrm{W}_{2}\right)$ & $844 \mathrm{gr}$ \\
\hline 3 & Berat benda uji $\left(\mathrm{W}_{3}\right)$ & $500 \mathrm{gr}$ \\
\hline 4 & Berat kering benda uji di oven + wadah $\left(\mathrm{W}_{4}\right)$ & $842 \mathrm{gr}$ \\
\hline 5 & Berat kering benda uji setelah di oven $\left(\mathrm{W}_{5}\right)$ & $498 \mathrm{gr}$ \\
\hline 6 & $\%$ Kadar lumpur pasir $=\left(\frac{W 3-w 5}{w 5} \times 100 \%\right)$ & $0,402 \%$ \\
\hline
\end{tabular}

(Sumber: Hasil analisis, 2018) 
3. Kadar Air Kerikil

Berdasarkan hasil pemeriksaan kadar air kerikil diperoleh hasil dalam pengujian ini sebesar $2,417 \%$. Hasil ini memenuhi syarat spesifikasi kadar air kerikil yaitu 3\%. Berikut ini hasil dari pengujian kadar air kerikil:

Tabel 7. Hasil Uji Kadar Air Kerikil

\begin{tabular}{|l|l|c|}
\hline No & \multicolumn{1}{|c|}{ Keterangan } & Hasil \\
\hline 1 & Berat wadah $\left(\mathrm{W}_{1}\right)$ & $344,0 \mathrm{gr}$ \\
\hline 2 & Berat benda uji + wadah $\left(\mathrm{W}_{2}\right)$ & $844,0 \mathrm{gr}$ \\
\hline 3 & Berat benda uji $\left(\mathrm{W}_{3}\right)$ & $500,0 \mathrm{gr}$ \\
\hline 4 & Berat kering benda uji di oven + wadah $\left(\mathrm{W}_{4}\right)$ & $832,2 \mathrm{gr}$ \\
\hline 5 & Berat kering benda uji setelah di oven $\left(\mathrm{W}_{5}\right)$ & $489,0 \mathrm{gr}$ \\
\hline 6 & $\%$ Kadar lumpur pasir $=\left(\frac{W 3-w 5}{w 5} \times 100 \%\right)$ & $2,417 \%$ \\
\hline
\end{tabular}

(Sumber: Hasil analisis, 2018)

4. Berat Jenis Kerikil dan Penyerapan Air

Pengujian berat jenis agregat kasar dan absorpsi air memberikan hasil berupa BJ kering agregat kasar sebesar 2,8\%, rata-rata berat jenis kondisi SSD sebesar 2,79\% serta 2,23\% penyerapan air.

Tabel 8. Hasil Uji Berat Jenis Kerikil dan Penyerapan Air ${ }^{[8]}$

\begin{tabular}{|c|l|l|}
\hline No & \multicolumn{1}{|c|}{ Keterangan } & \multicolumn{1}{|c|}{ Sampel } \\
\hline 1 & Berat agregat kasar (A) & $3000 \mathrm{gr}$ \\
\hline 2 & Berat kering agregat kasar (B) & $2933 \mathrm{gr}$ \\
\hline 3 & Berat agregat kasar dalam air (C) & $1882 \mathrm{gr}$ \\
\hline 4 & Berat jenis agregat kasar $\left(\frac{B}{A-C}\right)$ & 2,80 \\
\hline 5 & Saturated Surface Dry (SSD) $\left(\frac{A}{A-C}\right)$ & 2,79 \\
\hline 6 & $\%$ Penyerapan $\left(\frac{A-B}{B} \times 100 \%\right)$ & $2,23 \%$ \\
\hline
\end{tabular}

(Sumber: Hasil analisis, 2018)

\section{Hasil Nilai Slump Test}

Penelitian ini memberikan hasil nilai slump test yang diperoleh sesuai dengan nilai slump yang ditentukan, yakni $80 \mathrm{~mm}-150 \mathrm{~mm}$ dan termasuk dalam slump plastis. Hasil pengujian nilai slupm test dapat dilihat pada tabel berikut ini.

Tabel 9. Hasil Slump Test

\begin{tabular}{|c|l|c|}
\hline No & \multicolumn{1}{|c|}{ Sample Varian } & Nilai Slump $(\mathrm{cm})$ \\
\hline 1 & Varian Normal (LG 0\% + SB 0\%) & $11,0 \mathrm{~cm}$ \\
\hline 2 & Varian 1 (LG 20\% + SB 0\%) & $9,5 \mathrm{~cm}$ \\
\hline 3 & Varian 2 (LG 20\%+ SB 0,5\%) & $10,5 \mathrm{~cm}$ \\
\hline 4 & Varian 3 (LG 20\%+ SB 1,0\%) & $10,0 \mathrm{~cm}$ \\
\hline 5 & Varian 4 (LG 20\%+ SB 1,5\%) & $9,5 \mathrm{~cm}$ \\
\hline
\end{tabular}

(Sumber: Hasil analisis, 2018) 


\section{E. Hasil Uji Kuat Tekan Beton}

Pengujian kuat tekan beton rata-rata dapat dilihat pada tabel berikut:

Tabel 10. Hasil Kuat Tekan Beton

\begin{tabular}{|c|c|c|c|c|c|}
\hline $\begin{array}{c}\text { Umur } \\
\text { Pengujian } \\
\text { (hari) }\end{array}$ & $\begin{array}{c}\text { Beton Normal } \\
(\mathrm{LG} \mathrm{0 \% +SB} \mathrm{\% )} \\
(\mathrm{MPa})\end{array}$ & $\begin{array}{c}\text { Variasi 1 } \\
(\mathrm{LG} \mathrm{20 \% +} \\
\text { SB 0\% }) \\
(\mathrm{MPa})\end{array}$ & $\begin{array}{c}\text { Variasi 2 } \\
(\mathrm{LG} \mathrm{20 \% +} \\
\text { SB 0,5\% }) \\
(\mathrm{MPa})\end{array}$ & $\begin{array}{c}\text { Variasi 3 } \\
(\mathrm{LG} \mathrm{20 \% +} \\
\text { SB 1,0\% }) \\
(\mathrm{MPa})\end{array}$ & $\begin{array}{c}\text { Variasi 4 } \\
(\mathrm{LG} \mathrm{20 \% +} \\
\text { SB 1,5\% }) \\
(\mathrm{MPa})\end{array}$ \\
\hline 7 & 22,458 & 22,647 & 23,684 & 24,250 & 25,477 \\
\hline 14 & 24,628 & 26,987 & 26,610 & 26,894 & 28,684 \\
\hline 28 & 30,006 & 30,76 & 30,95 & 31,52 & 32,130 \\
\hline
\end{tabular}

(Sumber: Hasil analisis, 2018)

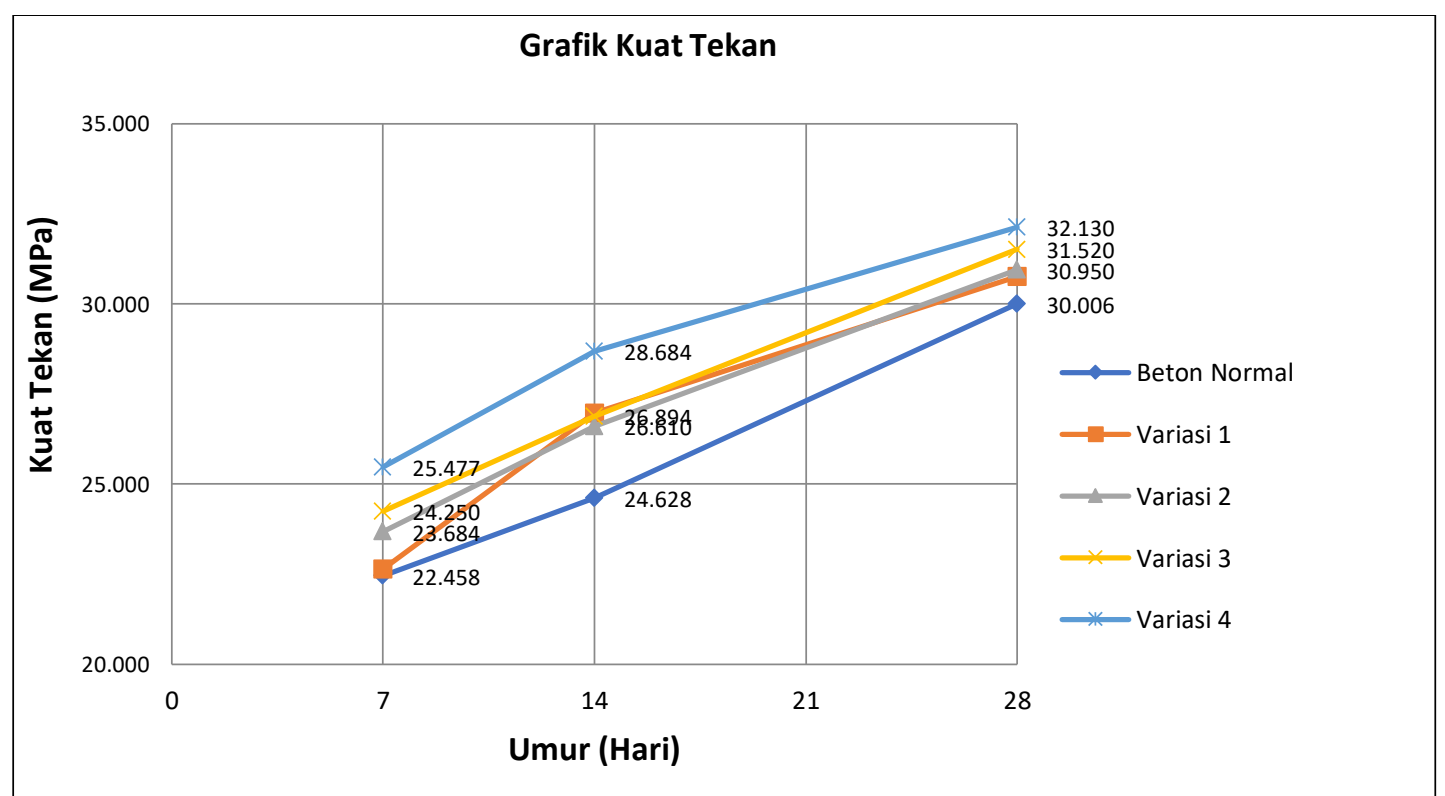

Gambar 1. Grafik Kuat Tekan Beton

(Sumber: Hasil analisis, 2018)

Berdasarkan tabel hasil rata-rata kuat tekan beton dan grafik hasil pengujian kuat tekan beton semua variasi diatas diperoleh kuat tekan tertinggi untuk beton sampel dengan variasi 4 yaitu campuran limbah geothermal 20\% + serat ban bekas 1,5\%, menghasilkan kuat tekan sebesar 32,130 MPa umur 28 hari. Nilai kuat tekan beton normal sebesar 30,006 MPa, maka beton variasi 4 memiliki kenaikan sebesar 7,08 \% dengan selisih 2,124 Mpa terhadap beton normal.

\section{F. Hasil Pengujian Kuat Tarik Belah Beton}

Berikut merupakan hasil pengujian kuat tarik belah beton:

Tabel 11. Hasil Tarik Belah Beton

\begin{tabular}{|c|c|c|c|c|c|c|c|}
\hline No & Campuran Variasi & $\begin{array}{c}\text { Benda } \\
\text { Uji }\end{array}$ & $\begin{array}{c}\text { Umur } \\
(\text { Hari })\end{array}$ & $\begin{array}{c}\text { Luas } \\
\text { Sampel } \\
\left(\mathrm{mm}^{2}\right)\end{array}$ & $\begin{array}{c}\text { Beban } \\
(\mathrm{kN})\end{array}$ & $\begin{array}{c}\text { Kuat } \\
\text { Tarik } \\
(\mathrm{MPa})\end{array}$ & $\begin{array}{c}\text { Rata- } \\
\text { Rata } \\
\text { Kuat }\end{array}$ \\
\hline
\end{tabular}




\begin{tabular}{|c|c|c|c|c|c|c|c|}
\hline & & & & & & & $\begin{array}{l}\text { Tarik } \\
(\mathrm{MPa}) \\
\end{array}$ \\
\hline \multirow{3}{*}{1} & \multirow{3}{*}{$\begin{array}{l}\text { Normal } \\
(\text { LG 0\%+ SB 0\%) }\end{array}$} & 1 & \multirow{3}{*}{28} & 141371,669 & 120 & 1,70 & \multirow{3}{*}{1,60} \\
\hline & & 2 & & 141371,669 & 110 & 1,57 & \\
\hline & & 3 & & 141371,669 & 110 & 1,57 & \\
\hline \multirow{3}{*}{2} & \multirow{3}{*}{$\begin{array}{l}\text { Variasi } 1 \\
(\text { LG 20\% + SB 0\%) }\end{array}$} & 1 & \multirow{3}{*}{28} & 141371,669 & 115 & 1,63 & \multirow{3}{*}{1,61} \\
\hline & & 2 & & 141371,669 & 110 & 1,57 & \\
\hline & & 3 & & 141371,669 & 115 & 1,63 & \\
\hline \multirow{3}{*}{3} & \multirow{3}{*}{$\begin{array}{l}\text { Variasi } 2 \\
(\text { LG 20\% + SB 0,5\%) }\end{array}$} & 1 & \multirow{3}{*}{28} & 141371,669 & 120 & 1,70 & \multirow{3}{*}{1,66} \\
\hline & & 2 & & 141371,669 & 120 & 1,70 & \\
\hline & & 3 & & 141371,669 & 110 & 1,57 & \\
\hline \multirow{3}{*}{4} & \multirow{3}{*}{$\begin{array}{l}\text { Variasi } 3 \\
(\text { LG } 20 \%+\text { SB 1,0\%) }\end{array}$} & 1 & \multirow{3}{*}{28} & 141371,669 & 125 & 1,77 & \multirow{3}{*}{1,73} \\
\hline & & 2 & & 141371,669 & 120 & 1,70 & \\
\hline & & 3 & & 141371,669 & 120 & 1,70 & \\
\hline \multirow{3}{*}{5} & \multirow{3}{*}{$\begin{array}{l}\text { Variasi } 4 \\
(\text { LG 20\% + SB 1,5\%) }\end{array}$} & 1 & \multirow{3}{*}{28} & 141371,669 & 140 & 1,98 & \multirow{3}{*}{1,80} \\
\hline & & 2 & & 141371,669 & 110 & 1,56 & \\
\hline & & 3 & & 141371,669 & 130 & 1,84 & \\
\hline
\end{tabular}

(Sumber: Hasil analisis, 2018)

Berdasarkan hasil pengujian beton variasi 4, campuran Lumpur Geothermal $20+1,5 \%$ Serat Ban Bekas, memiliki nilai kuat tarik belah maksimum 1,80 MPa pada saat umur 28 hari. Beton normal mempunyai kuat tarik belah maksimum 1,60 MPa, sehingga beton variasi 4 memiliki kenaikan sebesar 12,5\% dengan selisih 0,20 Mpa terhadap beton normal.

\section{F. Hasil Pengujian Absorpsi Beton}

Setelah pengujian kuat tarik belah beton, pada saat umur beton mencapai 28 hari dilakukan uji absorpsi beton. Hasil uji penyerapan tersaji pada tabel berikut:

Tabel 12. Hasil Uji Penyerapan

\begin{tabular}{|c|l|c|c|c|}
\hline No & Variasi Campuran & $\begin{array}{c}\text { Berat Setelah } \\
\text { Direndam }\end{array}$ & $\begin{array}{c}\text { Berat } \\
\text { Kering }\end{array}$ & Penyerapan \\
\hline 1 & Varian Normal (LG 0\% + SB 0\%) & $11,44 \mathrm{~kg}$ & $11,14 \mathrm{~kg}$ & $2,70 \%$ \\
\hline 2 & Varian 1 (LG 20\% + SB 0\%) & $11,66 \mathrm{~kg}$ & $11,31 \mathrm{~kg}$ & $3,09 \%$ \\
\hline 3 & Varian 2 (LG 20\% + SB 0,5\%) & $11,72 \mathrm{~kg}$ & $11,26 \mathrm{~kg}$ & $4,09 \%$ \\
\hline 4 & Varian 3 (LG 20\% + SB 1,0\%) & $11,88 \mathrm{~kg}$ & $11,39 \mathrm{~kg}$ & $4,32 \%$ \\
\hline No & Variasi Campuran & $\begin{array}{c}\text { Berat Setelah } \\
\text { Direndam } \\
(\mathrm{kg})\end{array}$ & $\begin{array}{c}\text { Berat } \\
\text { Kering } \\
(\mathrm{kg})\end{array}$ & $\begin{array}{c}\text { Absorbsi } \\
(\%)\end{array}$ \\
\hline 5 & Varian 4 (LG 20\% + SB 1,5\%) & 11,98 & 11,32 & 5,83 \\
\hline
\end{tabular}

(Sumber: Hasil analisis, 2018)

Hasil pengujian absorpsi untuk sampel beton variasi 4 yakni dengan campuran Lumpur Geothermal $20 \%$ + Serat Baja Ban Bekas 1,5\% memberikan hasil penyerapan maksimum 5,83\% dibandingkan dengan beton normal yang memiliki penyerapan sebesar $2,70 \%$. 


\section{G. Konversi Hasil Uji Kuat Tarik Belah Menjadi Kuat Lentur}

Pengujian kuat tarik belah dikonversikan menjadi kuat tarik lentur akan memberikan hasil sebagai berikut:

Tabel 13. Hasil Konversi Kuat Tarik Belah Menjadi Kuat Lentur ${ }^{[8]}$

\begin{tabular}{|c|c|c|c|c|c|c|c|}
\hline No & Variasi Campuran & $\begin{array}{c}\text { Benda } \\
\text { Uji }\end{array}$ & $\begin{array}{l}\text { Umur } \\
\text { (Hari) }\end{array}$ & Beban $(\mathrm{kN})$ & $\begin{array}{l}\text { Kuat } \\
\text { Tarik } \\
(\mathrm{MPa})\end{array}$ & $\begin{array}{l}\text { Kuat } \\
\text { Lentur } \\
(\mathrm{MPa})\end{array}$ & $\begin{array}{c}\text { Rata-Rata } \\
\text { Kuat } \\
\text { Lentur } \\
\text { (MPa) }\end{array}$ \\
\hline \multirow{3}{*}{1} & \multirow{3}{*}{$\begin{array}{c}\text { Beton Normal } \\
(\text { LG } 0 \%+\mathrm{SB} \\
0 \%)\end{array}$} & 1 & \multirow{3}{*}{28} & 120 & 1,70 & 2,329 & \multirow{3}{*}{2,210} \\
\hline & & 2 & & 110 & 1,57 & 2,151 & \\
\hline & & 3 & & 110 & 1,57 & 2,151 & \\
\hline \multirow{3}{*}{2} & \multirow{3}{*}{$\begin{array}{c}\text { Beton Variasi } 1 \\
(\mathrm{LG} 20 \%+\mathrm{SB} \\
0 \%)\end{array}$} & 1 & \multirow{3}{*}{28} & 115 & 1,63 & 2,233 & \multirow{3}{*}{2,206} \\
\hline & & 2 & & 110 & 1,57 & 2,151 & \\
\hline & & 3 & & 115 & 1,63 & 2,233 & \\
\hline \multirow{3}{*}{3} & \multirow{3}{*}{$\begin{array}{c}\text { Beton Variasi } 2 \\
(\mathrm{LG} 20 \%+\mathrm{SB} \\
0,5 \%)\end{array}$} & 1 & \multirow{3}{*}{28} & 120 & 1,70 & 2,329 & \multirow{3}{*}{2,270} \\
\hline & & 2 & & 120 & 1,70 & 2,329 & \\
\hline & & 3 & & 110 & 1,57 & 2,151 & \\
\hline \multirow{3}{*}{4} & \multirow{3}{*}{$\begin{array}{c}\text { Beton Variasi } 3 \\
(\mathrm{LG} 20 \%+\mathrm{SB} \\
1,0 \%)\end{array}$} & 1 & \multirow{3}{*}{28} & 125 & 1,77 & 2,425 & \multirow{3}{*}{2,361} \\
\hline & & 2 & & 120 & 1,70 & 2,329 & \\
\hline & & 3 & & 120 & 1,70 & 2,329 & \\
\hline \multirow{3}{*}{5} & \multirow{3}{*}{$\begin{array}{c}\text { Beton Variasi } 4 \\
(\mathrm{LG} 20 \%+\mathrm{SB} \\
1,5 \%)\end{array}$} & 1 & \multirow{3}{*}{28} & 140 & 1,98 & 2,713 & \multirow{3}{*}{2,457} \\
\hline & & 2 & & 110 & 1,56 & 2,137 & \\
\hline & & 3 & & 130 & 1,84 & 2,521 & \\
\hline
\end{tabular}

(Sumber: Hasil analisis, 2018)

Hasil konversi kuat Tarik belah menjadi kuat lentur untuk sampel beton variasi 4 yakni campuran Lumpur Geothermal 20\% + Serat Ban Bekas 1,5\% dengan nilai kuat lentur 2,457 MPa pada saat umur 28 hari. Perbandingan dengan kuat lentur beton normal sebesar 2,210 MPa, maka beton variasi 4 mengalami kenaikan kuat lentur sebesar 11,18\% dengan selisih 0,247 MPa terhadap beton normal.

\section{KESIMPULAN DAN SARAN}

Beberapa kesimpulan dapat ditarik dari penelitian mengenai pengaruh penambahan lumpur geothermal dan serat baja ban bekas terhadap beton. Kesimpulannya antara lain slump test tertinggi terdapat pada beton variasi 2 (LG 20\% + SB 0,5\%) sebesar 10,5 cm lebih rendah dari beton normal yang $11 \mathrm{~cm}$, yang terkecil pada pariasi 4 yaitu $9,5 \mathrm{~cm}$ sama dengan yang tanpa serat baja ban bekas. Beton Variasi 4 (1,5\% serat baja ban bekas + 20\% lumpur geothermal) mempunyai kuat tekan tertinggi yakni sebesar 32,13 MPa dibandingkan dengan beton normal sebesar 30,006 MPa naik sebesar $7,08 \%$. Nilai serapan air maksimum terdapat pada beton variasi 4 (1,5\% serat baja ban bekas + 20\% lumpur geothermal) sebesar 5,83\% yakni lebih besar jika dibandingkan dengan serapan air beton normal 2,70\%. Penggunaan serat ban bekas mempengaruhi kuat tarik belah sebesar 12,5\% pada campuran maksimum, yakni variasi 4 serat baja ban bekas 1,5\% dengan lumpur geothermal $20 \%$ yakni 1,8 MPa dibandingkan kuat tarik belah pada beton normal 1,6 MPa. Konversi kuat tarik belah tertinggi yaitu variasi 4 sebesar 2,457 MPa sedangkan beton normal 2,210 MPa, dengan kenaikan sebesar $11,18 \%$. 
Saran yang dapat diberikan dari hasil penelitian ini adalah perlu adanya tinjauan efisiensi biaya antara beton normal dan beton substitusi limbah lumpur geothermal dan baja bekas ban, adanya percobaan yang membandingkan beton dengan variasi geothermal, serta perlu adanya percobaan penggunaan serat baja ban bekas yang maksimum.

\section{DAFTAR PUSTAKA}

[1] Indonesia, S. N., \& Nasional, B. S. (2002). Metode pengujian kuat tarik belah beton.

[2] Permukiman, D., \& Prasarana, D. A. N. (2003). Perencanaan perkerasan jalan beton semen.

[3] Indonesia, S. N., \& Nasional, B. S. (2011). Cara uji kuat lentur beton normal dengan dua titik pembebanan.

[4] Indonesia, S. N., \& Nasional, B. S. (2011). Cara uji kuat tekan beton dengan benda uji silinder.

[5] Indonesia, S. N., \& Nasional, B. S. (2000). Tata cara pembuatan rencana campuran beton normal.

[6] Indonesia, S. N., \& Nasional, B. S. (2014). Spesifikasi agregat ringan untuk beton struktural Standard specification for lightweight aggregates.

[7] Indonesia, S. N., \& Nasional, B. S. (2002). Spesifikasi agregat halus untuk pekerjaan adukan dan plesteran dengan bahan dasar semen.

[8] Penambahan, P., Ash, F. L. Y., Plastik, D., Scale, M., \& Superplasticizer, D. A. N. (2018). Jurnal forum mekanika, 7(2). 